Lovering, R - The Problem of the Theistic Evidentialist Philosophers

\title{
The Problem of the Theistic Evidentialist Philosophers
}

\section{Rob Lovering}

\begin{abstract}
That theistic evidentialist philosophers have failed to make the evidential case for theism to atheistic evidentialist philosophers raises a problem - a question to be answered. I argue here that - of the most plausible possible solutions to this problem-each is either inadequate or, when adequate, in conflict with the theistic evidentialist philosophers' defining beliefs. I conclude that the problem of the theistic evidentialist philosophers - the question of why theistic evidentialist philosophers have failed to make their case to atheistic evidentialist philosophers-is a problem for theistic evidentialist philosophers-an objection to their defining beliefs.
\end{abstract}

\section{INTRODUCTION}

That theistic evidentialist philosophers (to be defined shortly) have failed to make the evidential case for theism to their skeptical counterparts-atheistic evidentialist philosophers-is a problem, or so I shall argue. The word "problem," of course, has at least two different senses. One sense of "problem" is "a question to be considered, solved, or answered"; while another is "a misgiving, objection, or complaint." In the following, I argue that there exists a problem in the first sense of the word which gives rise to a problem in the second sense of word. I call it the problem of the theistic evidentialist philosophers. Specifically, I argue that the fact that theistic evidentialist philosophers have failed to make their case to atheistic evidentialist philosophers raises a problem in the first sense-a question to be answered. I then argue that —of the most plausible possible solutions to this problemeach is either inadequate or, when adequate, in conflict with the theistic evi-

Rob Lovering, Department of Political Science, Economics, and Philosophy, CUNY College of Staten Island 


\section{PHIO}

dentialist philosophers' defining beliefs. Thus, I conclude that the problem of the theistic evidentialist philosophers-the question of why theistic evidentialist philosophers have failed to make their case to atheistic evidentialist philosophers-is a problem for theistic evidentialist philosophers-an objection to their defining beliefs.

To set the stage for the discussion of the problem of the theistic evidentialist philosophers, I ask the reader to consider the case of the world-class archeologists and the undiscovered goblet.

\section{The Case of the World-Class Archeologists and the UnDISCOVERED GOBLET}

Consider thousands of world-class archeologists-all exceptionally educated, intelligent, and experienced-who believe the following: (1) that an ancient, long-discussed but yet-to-be-discovered goblet exists; (2) that the existence of the goblet can be evidentially established, not simply in principle but in practice; and (3) that someone will indeed evidentially establish the existence of the goblet (if someone hasn't done so already).

Allow me to explain what I mean by (2) and (3). Regarding (2), by the goblet's existence being "evidentially established," I mean the goblet's existence can be made epistemically probable if not certain on the basis of inferential evidence. ${ }^{2}$ And when I say that the goblet's existence can be evidentially established "not simply in principle but in practice," I mean to rule out scenarios in which probabilifying, inferential evidence (hereafter, simply "evidence") of the goblet's existence exists but is inaccessible to humans. Suppose, for example, there is evidence of the goblet's existence in the form of a sound, but that the sound is outside the range in which human beings can hear. For present purposes, such is a scenario in which, though the goblet's existence could be evidentially established in principle, it could not be evidentially established in practice. And, regarding (3), I am simply trying to convey that these world-class archeologists do not believe that evidence of the goblet's existence will never be found.

Now, these world-class archeologists are ideally suited (intrinsically speaking) to discover evidence of the goblet's existence, if not the goblet itself. For, first, as world-class archeologists, they are educationally, intellectually, and experientially suited to discover evidence of the goblet's existence, if there is any. Moreover, given (1) - (3), they not only actively look for but expect to find evidence of the goblet's existence and, accordingly, are dispositionally suited to discover evidence of the goblet's existence. Given their level of education, intelligence, experience, and disposition, if anyone is suited to discover evidence of the goblet's existence, these world-class archeologists are.

Suppose, moreover, that the thousands of world-class archeologists who are actively looking for and expecting to find evidence of the goblet's existence have thousands of colleagues who are world-class archeologists of another sort. Though comparably educated, intelligent, and experienced as 


\section{РHIO}

the archeologists actively looking for and expecting to find evidence of the goblet's existence, these other archeologists do not believe that the goblet exists or ever existed and, accordingly, do not share the same disposition as those that do-i.e., they are not actively looking for and expecting to find evidence of the goblet's existence. For the sake of identification, let's refer to the archeologists actively looking for and expecting to find evidence of the goblet's existence as the "believers," and the archeologists who are not as the "skeptics." The degree of doubt among the skeptics varies from one archeologist to another, but all the skeptics agree that the believers have yet to make their case that, more likely than not, the goblet exists.

Looking in from the outside, one may wonder why the believers have failed to make their case to the skeptics. I will refer to this as the problem of the believer. I refer to this as the problem of the believer-as opposed to the problem of the skeptic-because it is the believer who actively looks for and expects to find evidence of the goblet's existence. And, I refer to it as the problem of the believer because "problem" can refer simply to a question to be answered. And, if there were such evidence, one wonders why they have not silenced their skeptical counterparts with it by now. After all, these believers are exceptionally qualified individuals-in terms of level of education, intelligence, experience, and disposition-and, along with their predecessors, have been actively looking for and expecting to find evidence of the goblet's existence for hundreds if not thousands of years now. That they haven't silenced their skeptical counterparts with evidence of the goblet's existence raises the question: why not? There are, I submit, a number of possible solutions to this problem, including:

The believers have discovered evidence of the goblet's existence and adequately articulated this (by objective measures) to the skeptics, but the skeptics haven't noticed due to their (the skeptics') intellectual inferiority.

The believers have discovered evidence of the goblet's existence and adequately articulated this to the skeptics, but the skeptics haven't noticed due to their dispositional inferiority.

The believers have discovered evidence of the goblet's existence, but thus far they have been unable to adequately articulate this evidence to the skeptics.

The believers have not discovered evidence of the goblet's existence thus far, but this is not a problem (in the second sense of "problem," i.e., an objection), since it doesn't follow from this that they won't.

The believers have not discovered evidence of the goblet's existence thus far, but this isn't a problem (an objection) since the skeptics have not discovered evidence of the non-existence of the goblet and, in turn, silenced their believing counterparts, either.

The believers have failed to make their case to their skeptical counterparts, but this is not surprising and, in turn, not a problem (an objection), since such is the nature of archeological disagreement.

One or more of the believers' defining beliefs-i.e., (1), (2), and (3)-is false.

One or more of the believers' defining beliefs is unintelligible. 
Lovering, R - The Problem of the Theistic Evidentialist Philosophers 5/6/2011 1:20 PM (1st Proof)

\section{PHIO}

These are among the most plausible possible solutions to the problem of the believer, I submit. Some of them may work together, of course-for example, perhaps (a) and (b) together adequately explain why the believers have failed to make their case to their skeptical counterparts. For present purposes, there is no need to analyze and evaluate these solutions, as the preceding is simply an attempt to illustrate and motivate the problem which is to be the focus of this paper, the problem of the theistic evidentialist philosophers.

\section{The Problem of the Theistic Evidentialist Philosophers}

By theistic evidentialist philosophers (or, TEPs), I mean philosophers who believe: $\left(1^{*}\right)$ that God exists; $(2 *)$ that God's existence can be evidentially established, not simply in principle but in practice; and $(3 *)$ that someone will indeed evidentially establish God's existence (if someone hasn't done so already).

Allow me to explain what I mean by $\left(1^{*}\right)-\left(3^{*}\right)$. Regarding $\left(1^{*}\right)$, by "God" I mean the god of what William Rowe refers to as "narrow theism," a being characterized by omnipotence, omniscience, and omnibenevolence, among other things. ${ }^{3}$ And by "exists," I mean exists in reality as opposed to exists only in the understanding.

Regarding $\left(2^{*}\right)$ and $(3 *)$, I mean the same thing, mutatis mutandis, as what I meant by (2) and (3) (above). So, regarding (2*), by God's existence being "evidentially established," I mean God's existence can be made epistemically probable if not certain on the basis of inferential evidence. (Some philosophers believe that God's existence can be established non-inferentially, of course, but the present project does not concern their position.) And when I say that God's existence can be evidentially established "not simply in principle but in practice," I mean to rule out scenarios in which probabilifying, inferential evidence of God's existence (again, simply "evidence") exists but is inaccessible to humans, such as evidence in the form of a sound that is outside the range in which human beings can hear. But another example is in order. Suppose that there is evidence of God's existence in the form of a sound but, this time, it is a sound that falls within the range of human hearing. Suppose also, however, that God deliberately blocks anyone from hearing the sound when hearing the sound would otherwise occur. In this case, too, though God's existence could be established in principle, it could not be established in practice. I raise this second example to make explicit that, given $\left(1^{*}\right)$ and $(2 *)$, God will not prevent all human beings from discovering the evidence of his existence. And, regarding $\left(3^{*}\right)$, I am simply trying to convey that TEPs do not believe that evidence of God's existence will never be found.

Two things about TEPs need to be noted. First, TEPs are to be distinguished, of course, from theists who deny one or more of the TEPs' defining beliefs, specifically, $(2 *)$ and $(3 *)$. Accordingly, the problem of the theistic evidentialist philosophers is not to be understood as the problem of the theists (simpliciter) or the problem of the theistic non-evidentialist philosophers, for theists 
Lovering, R - The Problem of the Theistic Evidentialist Philosophers

\section{PHIO}

(simpliciter) and theistic non-evidentialist philosophers might deny that God's existence can be evidentially established, or that someone will indeed evidentially establish God's existence (if someone hasn't done so already). The problem of the theistic evidentialist philosophers, then, arises from the conjunction of the TEPs' defining beliefs.

Second, as one can see, given my characterization of TEPs, one can be a theistic evidentialist philosopher without being formally trained in philosophy, let alone being a professional philosopher. That said, the problem of the theistic evidentialist philosophers discussed here pertains specifically to those TEPs who are professional philosophers or, at least, have enough philosophical training to be one. Hereafter, then, when I write of "theistic evidentialist philosophers," I have in mind individuals who are professional philosophers or have enough philosophical training to be one. Though examples of such TEPs are plethora, it will suffice to name just a few: Thomas Aquinas, William Paley, Robin Collins, William Lane Craig, Stephen T. Davis, C. Stephen Layman, and J. P. Moreland immediately come to mind. Even some of the philosophers who believe that God's existence can be established non-inferentially—such as Alvin Plantinga—may be considered theistic evidential philosophers, given the above definition. In Plantinga's case, he is a theistic philosopher who thinks (or, at least, at one time thought) that there is probabilifying, inferential evidence for God's existence in the form of an ontological argument. ${ }^{4}$ Accordingly, he is a theistic evidentialist philosopher as defined above.

Having covered the preceding, the problem of the theistic evidentialist philosophers may now be stated.

TEPs believe that God's existence can be evidentially established, not simply in principle but in practice, and that someone will indeed evidentially establish God's existence (if someone hasn't done so already). Moreover, as professional philosophers, they are ideally suited (intrinsically speaking) to discover evidence of God's existence. For, first, as professional philosophers, they are educationally, intellectually, and experientially suited to discover evidence of God's existence, if there is any. Moreover, given $(1 *)-(3 *)$, TEPs not only actively look for but expect to find evidence of God's existence and, accordingly, are dispositionally suited to discover evidence of God's existence. Given their level of education, intelligence, experience, and disposition, if anyone is suited to discover evidence of God's existence, TEPs are.

Now, there are currently hundreds if not thousands of such TEPs actively looking for and expecting to find evidence of God's existence. (When their predecessors are included, the number of TEPs is likely in the tens of thousands, if not more.) Moreover, these TEPs have an even greater number of colleagues - of comparable levels of education, intelligence, and experience-who believe that God does not exist and, accordingly, do not expect to find evidence of God's existence. I'll refer to the latter as "atheistic evidentialist philosophers" (or, AEPs). I say "an even greater number" since, according to a recent survey, only $15 \%$ of professional philosophers accept or lean toward theism, while $73 \%$ accept or lean toward atheism. ${ }^{5}$ 
Lovering, R - The Problem of the Theistic Evidentialist Philosophers 5/6/2011 1:20 PM (1st Proof)

\section{PHIO}

The degree of doubt among AEPs varies from one individual to another, undoubtedly, but they all agree that TEPs have yet to make their case that, more likely than not, God exists.

Looking in from the outside, one wonders why TEPs of such levels of education, intelligence, experience, and disposition have failed to make their case to their skeptical counterparts. This is what I refer to when I refer to the problem of the theistic evidentialist philosophers. I refer to this as the problem of the theistic evidentialist philosophers-as opposed to the problem of the atheistic evidentialist philosophers-because it is the theistic evidentialist philosophers who actively look for and expect to find evidence of God's existence. And, I refer to it as the problem of the theistic evidentialist philosophers because, again, "problem" can simply refer to a question to be answered. And, if there were such evidence, one wonders why TEPs have not silenced their skeptical counterparts with it by now. After all, these TEPs are exceptionally qualified individuals-in terms of level of education, intelligence, experience, and disposition - and, along with their predecessors, have been actively looking for and expecting to find evidence of God's existence for hundreds if not thousands of years now. That they haven't silenced their skeptical counterparts with evidence of God's existence raises the question: why not? There are, I submit, a number of possible solutions to this problem, which I will discuss shortly. But, before doing so, three caveats are in order.

First, as stated previously, "problem" can simply refer to a question to be answered rather than an objection. However, when a question goes unanswered or inadequately answered, the former sense of "problem" gives rise to the latter sense of "problem." In what follows, the "problem" of the theistic evidentialist philosophers is understood initially as a question to be answered. However, I will argue that, regarding the most plausible possible solutions, each is either inadequate or, when adequate, in conflict with the TEPs' defining beliefs and, thus, that the problem of the theistic philosophers (in the first sense of "problem") gives rise to a problem in the second sense of "problem"-an objection to their defining beliefs.

Second, given that I have chosen to refer to this issue as the problem of the theistic evidentialist philosophers, some readers may think that I am committing the ad hominem fallacy. Were they to do so, however, they would be mistaken since, fundamentally, what's at issue here is the TEPs' defining beliefs-i.e., $\left(1^{*}\right)-\left(3^{*}\right)$-not the TEPs themselves. To be sure, the problem of theistic evidentialist philosophers involves claims about TEPs themselves. But, this is because TEPs are the most suited collectors and presenters of evidence of God's existence, if there is any-just as, in the case of the undiscovered goblet, the believers are most suited collectors and presenters of evidence of the goblet, if there is any. As such, claims about the TEPs themselves-specifically, their failure to make their case to their skeptical counterparts-are relevant and thereby non-fallacious. ${ }^{6}$ For, if $\left(1^{*}\right)-\left(3^{*}\right)$ are true, as TEPs believe, and if TEPs are the most suited individuals to demonstrate this, then the fact that they haven't done so (a claim about TEPs themselves) is relevant to determining whether $\left(1^{*}\right)-\left(3^{*}\right)$ are indeed true. 
Lovering, R - The Problem of the Theistic Evidentialist Philosophers

Finally, some readers may think that the problem of the theistic evidentialist philosophers is question-begging, believing it implies that TEPs have lacked, continue to lack, and forever will lack evidence of God's existence. It should be made clear that the problem of the theistic evidentialist philosophers does not imply this. The problem of the theistic evidentialist philosophers is simply this: if, as TEPs believe, there is probabilifying, inferential evidence of God's existence, why have TEPs failed to make their case to their skeptical counterparts with it? As one can see, this question begs no questions with respect to God's existence or the existence of evidence thereof.

There are, of course, a number of possible solutions to the problem of the theistic evidentialist philosophers. But, of the most plausible possible candidates, each is either inadequate or, when adequate, in conflict with the TEPs' defining beliefs. Let us begin with the inadequate solutions.

\section{Inadequate Solutions to the Problem of the Theistic Evidentialist PHILOSOPHERS}

TEPs have discovered evidence of God's existence and adequately articulated this (by objective measures) to AEPs, but AEPs haven't noticed due to their (AEPS') intellectual inferiority.

This solution strikes me as rather unlikely. Simply put, it's very hard to believe that Aquinas's, Paley's, Davis's, and Craig's skeptical counterpartse.g., Michael Tooley, J. L. Schellenberg, Graham Oppy, Michael Martin, and William Rowe, among others-are intellectually inferior to TEPs in such a way that they simply do not (sufficiently) comprehend the evidence TEPs have adequately articulated (ex hypothesi) in favor of God's existence. Indeed, some of these philosophers have collaborated with and debated each other without accusing the other of (seriously) misunderstanding his own view. ${ }^{7}$ This is not to say that misunderstanding between TEPs and their skeptical counterparts does not occur, only that it's unlikely that a general intellectual inferiority on the part of AEPs suffices to explain why TEPs have failed to make their case to their skeptical counterparts.

TEPs have discovered evidence of God's existence and adequately articulated this to AEPs, but AEPs haven't noticed due to their dispositional inferiority.

By AEPs being "dispositionally inferior" to TEPs, I intend to convey that they are somehow culpably ignorant of the evidence of God's existence, perhaps because they have willfully rejected it or because they have willfully refused even to consider it. Whether they have willfully rejected evidence of God's existence or refused to consider it is, of course, an empirical matter. And I, for one, am not aware of any empirical study of this having been conducted, let alone having established that AEPs are so culpably ignorant. Accordingly, barring simply assuming a particular theology to be true (e.g., Calvinism, with its tenet of total depravity) and, in turn, believing that AEPs are so culpably ignorant, it seems unlikely that AEPs en masse have willfully 
Lovering, R - The Problem of the Theistic Evidentialist Philosophers 5/6/2011 1:20 PM (1st Proof)

rejected evidence of God's existence or refused to consider it, just as it is rather unlikely that TEPs en masse have willfully rejected evidence of the non-existence of God or refused to consider it. Moreover, if TEPs were to believe that AEPs are dispositionally inferior by simply assuming a particular theology to be true, AEPs could likewise assume an $a$ theology of one sort or another to be true which entails that TEPs are the ones who are dispositionally inferior - an atheology that includes, say, Freud's view that religious belief is comparable to a childhood neurosis. ${ }^{8}$ This, of course, would do nothing more than lead to an impasse.

Theologies aside, there is no doubt that some AEPs may have willfully rejected evidence of God's existence or refused to consider it-everyone is subject to prejudice or other irrational or non-rational factors from time to time, after all. But that some may have done so fails to explain why TEPs have failed to make their case to those AEPs who haven't willfully rejected evidence of God's existence or refused to consider it. Of course, TEPs might think that most if not all AEPs have willfully rejected evidence of God's existence or refused to consider it. But, again, without first assuming a particular theology to be true, this is rather unlikely, just as it is rather unlikely that, atheologies aside, most if not all TEPs have willfully rejected evidence of the non-existence of God or refused to consider it.

Another reason to think that this solution is inadequate has to do with the fact that TEPs argue with AEPs over more than just God's existence. For example, they also argue over issues of ethics, politics, science, and more. ${ }^{9}$ Now, hardly anyone-including TEPs themselves-would hold that, when it comes to disagreements between TEPs and their skeptical counterparts on these issues, an adequate explanation of this is that AEPs are dispositionally inferior to TEPs. Why, then, would one think that, when it comes to disagreement between TEPs and AEPs on another issue-namely, evidence of God's existence-an adequate explanation of this is that AEPs are dispositionally inferior to TEPs? Once again, without first assuming a particular theology to be true, such an explanation is unlikely.

With that said, what strikes me as most likely is that neither party-en masse, at any rate-is guilty of willfully rejecting evidence or refusing to consider it. If this is indeed the case, the solution currently under consideration is inadequate.

TEPs have discovered evidence of God's existence and adequately articulated this to AEPs, but AEPs haven't noticed due to God's preventing them from noticing.

For example, perhaps God blinds AEPs to the evidence of his existence for one reason or another, just as God hardened Pharaoh's heart, according to the Old Testament. ${ }^{10}$

There are a number of problems with this solution, the first of which is that, without first assuming a particular theology to be true, this solution appears ad hoc. To motivate this, consider, again, the case of the undiscovered goblet. Suppose the believers explained their failure to make their case to their skeptical counterparts on the grounds that evidence of the goblet 
Lovering, R - The Problem of the Theistic Evidentialist Philosophers

\section{PHIO}

may be found only by those who already believe-or, at least, are disposed to believe- that the goblet exists. This may be true, but looking in from the outside, such an explanation appears $a d$ hoc. Or, to use a more suitable analogy, suppose members of Raëlism-a religion that teaches that life on Earth was scientifically created by a species of extraterrestrials-explained their failure to make their case to their skeptical counterparts on the grounds that evidence of the extraterrestrials may be found only by those who already believe or are disposed to believe that the extraterrestrials exist. ${ }^{11}$ This may be true, but looking in from the outside, such an explanation appears ad hoc. And so it is, I submit, with this solution to the problem of the theistic evidentialist philosophers as it amounts to saying that evidence of God's existence may be found only by those who already believe or are disposed to believe that God exists. Again, this may be true, but it appears ad hoc.

Of course, to appear to be ad hoc is not one and the same as actually being ad hoc. And, if the explanation under consideration is not actually ad hoc and is plausible, then it is likely ... if God exists. ${ }^{12}$ But, regarding plausibility, this explanation is simply implausible. You see, this explanation implies that evidence may now be divided into the following two categories: (a) evidence that can be discovered only if one believes or is disposed to believe in the existence of that of which it is evidence and (b) evidence that can be discovered regardless of whether one believes or is disposed to believe in the existence of that of which it is evidence. Now, every debate-philosophical or otherwise-of which heretofore I have been aware relies upon evidence of the latter sort. But, if this explanation is acceptable, then we would have to grant that the debate on God's existence-and, more importantly, perhaps many other debates-rely upon evidence of the former sort. But this strikes me as implausible for a number of reasons. To begin with, it flies in the face of the evidentialist approach to philosophical debates, and TEPs are just that, evidentialists. David Hume summarized the evidentialist approach to philosophical debates with his dictum, "A wise man ... proportions his belief to the evidence." ${ }^{13}$ Yet, in effect, the explanation under consideration stands Hume's dictum on its head, asking us to proportion the evidence to our beliefs or, at least, our disposition to believe.

Another reason to think the explanation is implausible is as follows. Suppose you do not believe that Platonic Forms-or other minds, or extraterrestrial aliens, or unicorns, or what have you-exist, as you have not discovered evidence of these things. If the explanation under consideration is acceptable, it may be that the evidence you've been looking for is not the right sort of evidence for these things. It may be that the right sort of evidence for these things is the evidence that can be discovered only if one believes or is disposed to believe in the existence of that of which it is evidence. This may be possible, but it's rather implausible—one's believing or being disposed to believe that other minds, extraterrestrials, unicorns, or what have you exist seems to have no bearing whatsoever on whether evidence thereof exists or can be discovered. (To be sure, believing or being disposed to believe in the existence of evidence bears upon whether evidence 
will be found; after all, if one does not think that evidence exists one way or the other, then one will not attempt to look for it. But believing or being disposed to believe in the existence of that of which it is (or is not) evidence seemingly does not.) Granted, the sort of evidence that can be discovered only if one believes or is disposed to believe in the existence of that of which it is evidence may apply to only one thing: God. But this brings us full circle, as such appears ad hoc.

Regarding this explanation being likely if God exists, this may be true, but it's not clear that this would suffice for deeming the solution under consideration adequate. TEPs may find it to be adequate, to be sure, but I'm quite confident AEPs would not as the likelihood is conditional upon something they reject, namely, theism. And I'm equally confident that agnostic evidentialist philosophers would tend to side with the AEPs in this regard. If more than just the TEPs are to be satisfied with this explanation, we need to get beyond the conditional "If God exists, then explanation (c*) is likely" to an affirmation of the antecedent "God exists" from which me may deduce "Explanation ( $\left.\mathrm{c}^{*}\right)$ is likely." But, in the present context, an explanation for why TEPs have failed to make their case to AEPs that depends upon the truth of the claim "God exists" will be compelling only for TEPs themselves. Finally, if TEPs accepted the explanation under consideration and really believed that God prevents their skeptical counterparts from discovering evidence of God's existence, why would they continue to participate in what by their own lights must be nothing more than a farce, namely, arguing with AEPs over the issue of God's existence? Perhaps it is because they believe God has commanded them to do so, or because they enjoy doing so. But, given the explanation under consideration, they couldn't be doing so because they believed that a genuine dialogue regarding the truth of the matter could be had with AEPs.

TEPs have discovered evidence of God's existence, but thus far they have been unable to adequately articulate this evidence to their skeptical counterparts.

Specifically, it may be that the evidence there is of God's existence is difficult not simply to find but to understand and articulate. Indeed, the most recent versions of the classical arguments for God's existence-the cosmological, ontological, and teleological arguments-lend support to this hypothesis. Each of these arguments includes concepts or demonstrations that even TEPs themselves have trouble understanding and performing, respectively. For example, one of the more recent articulations of the Kalam cosmological argument invokes the concept of metaphysical time (not to confused with physical time $) ;{ }^{14}$ one of the more recent articulations of the ontological argument invokes the modal concepts of possible worlds and maximal greatness and the S5 axiom of modal logic: ${ }^{15}$ and one of the more recent articulations of the teleological argument involves attempting to demonstrate the irreducible complexity of things such as the bacterial flagellum and the immune system. ${ }^{16}$ Needless to say, even the best of minds may have trouble adequately understanding and articulating to others evidence that relies on 
such concepts and demonstrations: in some cases because the concepts employed are inherently difficult to understand, in others because the demonstrations - and the understandings thereof-require a robust understanding of another discipline, such as molecular biology.

Now, it may indeed be that the evidence there is of God's existence is difficult not only to find but to understand and articulate. But, there's something very troubling about this solution to the problem of the theistic evidentialist philosophers. Simply put, it's utterly baffling that God would decide to provide evidence of his existence but to provide it in such a bizarre-indeed, seemingly haphazard-and inscrutable way; so inscrutable that, ex hypothesi, those who are most suited to do so (TEPs) struggle to understand the evidence, let alone to adequately articulate it to their skeptical counterparts. (I write "decide" deliberately, since I am assuming that (a) God could have prevented us from having or, at least, discovering evidence of his existence and (b) God would not leave the matter of evidence of his existence to chance.)

To motivate this point, consider the version of the teleological argument that invokes the alleged irreducible complexity of the bacterial flagellum. Proponents of this argument would have us believe that God has provided evidence of his existence and that it can be found in the form of the irreducible complexity of the bacterial flagellum. But it is very difficult to understand why God would do this, let alone believe it. Of all the places where God could have provided evidence of his existence-particularly biological evidence-are we to believe that he decided to provide it in the bacterial flagellum, something the existence and nature of which was known by no one prior to the development of molecular biology and is known by almost no one even after the development of molecular biology? (Special creation of species - the very thing many proponents of the irreducible complexity arguments reject-would have been too obvious, I suppose.) This strains the limits of understanding and belief.

Or consider the version of the Kalam cosmological argument which invokes the concept of metaphysical time. Of all the ways God could have provided evidence of his existence, are we to believe that God decided to provide it in a way that requires understanding of the concept of metaphysical time, a concept that even those who rely upon it seem to struggle to understand? As one critic of this version of the Kalam cosmological argument observes, "The nature of metaphysical time and its relation to physical time are large and difficult questions"-an understatement if there ever was one. ${ }^{17}$ Again, this strains the limits of understanding and belief.

To be sure, God may not want evidence of his existence to be too obvious for one reason or another, or God may not care one way or the other whether we find evidence of his existence. But, regarding the former, providing evidence in the form of, say, the irreducible complexity of the bacterial flagellum in order to ensure that the evidence isn't too obvious strikes me as overly and unreasonably cautious, especially when considered in the light of the explanation under consideration. For, given the explanation 


\section{PHIO}

under consideration, the evidence is so difficult to understand and adequately articulate that even those best suited to do so (TEPs) have thus far failed to do so.

As for the latter, it may be that God does not care one way or the other whether we find evidence of his existence. But if TEPs believe this to be the case, then a troubling question arises. If God does not care one way or the other whether we find evidence of his existence, what reasons does God have for deciding to provide any evidence of his existence whatsoever, for deciding to allow some of us to discover this evidence, for deciding to provide said evidence in the form of the irreducible complexity of the bacterial flagellum or arguments relying upon the concepts of possible worlds and metaphysical time? I ask for reasons for doing these things deliberately since I am assuming that God does not do things willy-nilly. Why would God who, ex hypothesi, does not care one way or the other whether we find evidence of his existence, decide nevertheless to provide evidence of his existence and do so in such a bizarre and inscrutable way? What, quite literally, is God thinking? It's such a baffling scenario that, upon searching for reasons with just the slightest plausibility, I draw a blank. To motivate this point, consider the following analogy.

Suppose a woman gives birth to a child and immediately gives the child up for adoption. Thereafter, the child has no contact with his birth-mother and, as far as the child knows, his adopted-mother is his birth-mother. Suppose further that the birth-mother does not care one way or the other whether her child discovers evidence of her existence. Even so, she decides to provide evidence of her existence that her child may discover and does so in a bizarre and inscrutable way. For example, she decides to write letters about her existence to her child using Egyptian hieroglyphs, something very few people on the planet can understand and translate. And, she decides to plant these letters in the chimney of the child's house, buried in the cement that fastens the bricks together. If the birth-mother does not care one way or the other whether her child discovers evidence of her existence, what reason does she have for deciding to provide any evidence of her existence whatsoever? And, what reason does she have for providing said evidence in the form of letters written in Egyptian hieroglyphs buried between bricks in the chimney? What, quite literally, is the birth-mother thinking?

There are, of course, many disanalogies between the two cases. For example, the birth-mother can have bad reasons for doings what she does while God cannot, and the letters are arguably easier to discover than irreducibly complex bacterial flagella. But I trust that the analogy serves the purpose of motivating the question: if God does not care one way or the other whether we find evidence of his existence, what reasons does he have for deciding to provide evidence of his existence nevertheless and to do so in such a bizarre, inscrutable way? What is God thinking? Remember, God could have prevented us from having or discovering evidence of his existence, and he would not leave the matter of evidence of his existence to chance. Accordingly, even if God was simply thinking that he wanted to cre- 


\section{PHIO}

ate irreducibly complex things-just for kicks, as it were-he could have prevented us from discovering any of them. But, ex hypothesi, he didn't prevent us from discovering any of them. So, again, what reasons does God have for deciding to provide evidence of his existence nevertheless and to do so in such a bizarre, inscrutable way? What is God thinking? I'm not suggesting that no plausible answer to this question is forthcoming. But I am suggesting that, unless a plausible answer to this question is offered, the explanation under consideration-particularly when combined with the hypothesis that God does not care one way or the other whether we find evidence of his existence-is very difficult to believe. (It should be noted here that I do not think that appeals to mystery or skeptical theism make for plausible answers to this question. ${ }^{18}$ )

Finally, if nothing else, many TEPs—such as Craig and Aquinas-are exceptionally skilled at articulating philosophical concepts, distinction, positions, and arguments. Given this, it's hard to believe that, when it comes to evidence of God's existence-Craig's and Aquinas's bread and butter, as it were-they simply have not been able to adequately articulate it to their skeptical counterparts.

TEPs haven't discovered evidence of God's existence thus far, but this is not a problem (in the second sense of "problem," i.e., an objection), since it doesn't follow from this that they won't.

This may be true. But, if so, it is a rather hard pill for TEPs to swallow. After hundreds if not thousands of years, with tens of thousands of the most suited individuals giving a tremendous amount of serious and critical thought to this issue (TEPs), it's really hard to believe that all that is needed is more time. After all, by their own lights, they're searching for evidence of a god who, ex hyposthesi, decided to provide evidence of his existence, evidence that is discoverable not simply in principle but in practice.

Also, in the vein of the reply to the preceding solution $\left(\mathrm{d}^{*}\right)$, it's simply baffling that God would decide to provide evidence of his existence but do so such a way that so much time, energy, intellectual expertise, and more is needed to find it.

TEPs haven't discovered evidence of God's existence thus far, but this isn't a problem (an objection) since AEPs haven't discovered evidence of the non-existence of God and, in turn, silenced their theistic counterparts with it, either.

There are a number of problems with this explanation. First, if, ex hypothesi, TEPs have not found evidence of God's existence thus far, it's very hard to believe that this could be anything but a problem. In the vein of previous replies $\left(\left(\mathrm{d}^{*}\right)\right.$ and $\left.\left(\mathrm{e}^{*}\right)\right)$, after hundreds if not thousands of years, with tens of thousands of the most suited individuals giving a tremendous amount of serious and critical thought to this issue (TEPs), it's really hard to believe that such evidence exists but that TEPs haven't found it. Again, they are, after all, searching for evidence of a god who decided to provide evidence of his existence, evidence that is discoverable not simply in principle but in practice. 
Second, from the fact-if it is a fact-that AEPs have not discovered evidence of the non-existence of God, it does not follow that the TEPs' failure to discover evidence of God's existence is not a problem. If anything, what follows is that both TEPs and AEPs face a problem. In turn, agnosticism-or perhaps a Wittgensteinian silence, if you will—may be the solution. ${ }^{19}$

Finally, it's not clear that TEPs and AEPs are such strict counterparts to each other such that, if the failure to discover evidence of God's existence is a problem for TEPs, then the failure to discover evidence of God's non-existence must be a problem for AEPs. There is a significant difference between the failure to discover evidence of the existence of something, and failure to discover evidence of the non-existence of something. All else being equal, failure to discover evidence of the existence of $\mathrm{X}$ is prima facie evidence of the non-existence of $\mathrm{X}$; while, failure to discover evidence of the non-existence of $\mathrm{X}$ is not prima facie evidence of the existence of $\mathrm{X}$. Consider, for example, the case of the undiscovered goblet once more. All else being equal, the believers' failure to discover evidence of the goblet is prima facie evidence of the non-existence of the goblet; while the skeptics' failure to discover evidence of the non-existence of the goblet is not prima facie evidence of the existence of the goblet. Similarly, all else being equal, the TEPs' failure to discover evidence of the existence of God-evidence TEPs believe exists and is discoverable in practice-is prima facie evidence of the non-existence of God; while the AEPs' failure to discover evidence of the non-existence of God is not prima facie evidence of the existence of God. Given this, it's simply not the case that, if the failure to discover evidence of God's existence is a problem for TEPs, then the failure to discover evidence of God's non-existence is a problem for AEPs.

TEPs have failed to make their case to their skeptical counterparts, but this is not surprising and, in turn, not a problem (an objection), since such is the nature of philosophical disagreement.

Granted, when it comes to philosophical disagreement, it may not be surprising that TEPs have failed to make their case to AEPs. Indeed, it's hard to think of many philosophical disagreements that, after much debate, has resulted in one side of the argument making their case to the other side. Even so, it doesn't follow from this that their failure to do so is not a problem. And, if what I am arguing here is correct, then the fact that TEPs have failed to make their case to AEPs is problematic indeed. For, as stated previously, when a question goes unanswered or inadequately answered, the former sense of "problem" gives rise to the latter sense of "problem." Presently, I am arguing that, regarding the most plausible possible solutions, each is either inadequate or, when adequate, in conflict with the TEPs' defining beliefs and, thus, that the problem of the theistic philosopher (in the first sense of "problem") gives rise to a problem in the second sense of "problem"-an objection to their defining beliefs. That the lack of an adequate answer is unsurprising does nothing to alleviate this. 


\section{PHIO}

\section{Adequate Solutions to the Problem of the Theistic Evidentialist PhILOSOPHeRS}

Having covered a number of inadequate solutions, I'd like to conclude with two adequate solutions. They are "adequate" in a way similar to the way J. L. Mackie's "adequate solutions" to the logical problem of evil are adequate- they solve the problem, but not in a way TEPs will find agreeable.

One or more of the TEPs' defining beliefs- $\left(1^{*}\right),\left(2^{*}\right)$, and $\left(3^{*}\right)$ —is false.

TEPs won't find this solution to be very attractive, of course; they are, after all, TEPs. Even so, were one to deny, say, that God exists, or that God's existence can be evidentially established, not simply in principle but in practice, then one could adequately explain why TEPs have failed to silence their skeptical counterparts with evidence of God's existence.

One or more of the TEPs' defining beliefs is unintelligible.

Like the preceding solution, TEPs won't find this solution to be very attractive. Even so, were one to hold that the belief, say, that the proposition captured by the claim "God exists" is unintelligible and thereby neither true nor false, then one could adequately explain why TEPs have failed to silence their skeptical counterparts with evidence of God's existence.

\section{CONCLUSION}

I have argued here that the fact that theistic evidentialist philosophers have failed to make the case for theism to atheistic evidentialist philosophers raises a problem-a question to be answered. I have also argued that-of the most plausible possible solutions to this problem-each is either inadequate or, when adequate, in conflict with the theistic evidentialist philosophers' defining beliefs. Thus, I conclude that the problem of the theistic evidentialist philosophers-the question of why theistic evidentialist philosophers have failed to make their case to atheistic evidentialist philosophersis a problem for theistic evidentialist philosophers-an objection to their defining beliefs.

\section{ACKNOWLEDGEMENTS}

I would like to thank Paul Draper, Paul Studtmann, and Steve Morris for their comments on earlier drafts of this paper.

\section{NOTES}

1. http://www.answers.com/main/ntquery?s=problem $\&$ gwp $=13$.

2. Inferential evidence of the existence of something is perhaps best understood when contrasted with non-inferential evidence of the existence of something. Noninferential evidence of the existence of $\mathrm{X}$ is evidence that involves direct observation of X. Inferential evidence of the existence of X, on the other hand, is evidence that 
Lovering, R - The Problem of the Theistic Evidentialist Philosophers

\section{PHIO}

does not involve direct observation of $\mathrm{X}$ but evidence from which we may infer the existence of $\mathrm{X}$.

3. See William Rowe, Philosophy of Religion: An Introduction, 4th edition (Belmont, Cal.: Thomson Wadsworth, 2007), p. 17.

4. See Alvin Plantinga, God, Freedom, and Evil (Grand Rapids, Mich.: Eerdmans, 1974), pp. 85ff. Of course, Plantinga does not think that his version of the ontological argument proves that God exists. But this does not mean that he does not believe there is inferential, probabilifying evidence of God's existence. For, believing there is inferential, probabilifying evidence of God's existence is not one and the same as believing there is proof of God's existence. And Plantinga clearly believes that his version of the ontological argument is an instance of inferential, probabilifying evidence of God's existence. Simply put, he thinks it is a sound argument: that it is valid and that all of the premises are true. To be sure, he concedes that "not everyone who understands and reflects on its central premise - that the existence of a maximally great being is possible-will accept it" (Plantinga, p. 112). But believing there is inferential, probabilifying evidence of God's existence does not necessitate believing that everyone who understands and reflects on the evidence will accept it.

5. http://philpapers.org/surveys/results.pl?affil = Target + faculty\&areas $0=0 \&$ careas $\max =1 \&$ grain $=$ coarse .

6. Not all ad hominem arguments are fallacious. See Douglas Walton, Informal Logic: A Pragmatic Approach (Cambridge, UK: Cambridge University Press), pp. $190 \mathrm{ff}$.

7. See, for example, Alvin Plantinga and Michael Tooley, Knowledge of God (Malden, MA: Blackwell, 2008).

8. See Sigmund Freud, The Future of an Illusion (New York: W. W. Norton, 1989).

9. See, for example, Daniel Dennett and Alvin Plantinga, Science and Religion: Are They Compatible? (New York: Oxford University Press).

10. Exodus 10:20. For a defense of a view along these lines, see Paul K. Moser, "Cognitive Idolatry and Divine Hiding," in Divine Hiddenness, ed. D. Howard-Snyder and P. K. Moser (Cambridge, UK: Cambridge University Press, 2002), pp. 120-148.

11. http://en.wikipedia.org/wiki/Ra\%C3\%ABlism.

12. Thanks to Paul Draper for pointing this out.

13. David Hume, "Against Miracles," in Philosophy of Religion: An Anthology, ed. Louis Pojman and Michael Rea (Belmont, Cal.: Thomson Wadsworth, 2008), p. 277.

14. William Lane Craig, "The Origin and Creation of the Universe: A Response to Adolf Grünbaum," British Journal for the Philosophy of Science 43 (1992), pp. 233-240.

15. See Plantinga, God, Freedom, and Evil, pp. $85 \mathrm{ff}$.

16. See Michael Behe, Darwin's Black Box: The Biochemical Challenge to Evolution (New York: Free Press, 1998).

17. Wes Morriston, "A Critique of the Kalam Cosmological Argument," in God Matters: Readings in the Philosophy of Religion, ed. Ray Martin and Christopher Bernard (New York: Longman, 2002), pp. 95-108.

18. Regarding appeals to skeptical theism, see my "On What God Would Do," International Journal for Philosophy of Religion 66.2 (2009): 87-104. Regarding appeals to mystery, see my "Divine Hiddenness and Inculpable Ignorance," International Journal for Philosophy of Religion 56.2-3 (2004): 103ff.

19. Thanks to Paul Studtmann for pointing this out. 